\title{
ASPECTS-DWI における領域別早期虚血変化と
}

\section{rt-PA 静注療法後の脳梗塞患者の転帰}

\begin{tabular}{|c|c|c|c|c|c|c|c|}
\hline 祢津 智久 ${ }^{1)}$ & 古盁 & 政利 ${ }^{1111)}$ & 沼 & 雅基 ${ }^{1111)}$ & 木村 & 和美2)11) & 塩川 芳昭 ${ }^{3) 11)}$ \\
\hline 譲二4)1 & 古井 & 英介 ${ }^{5) 11)}$ & 上 & 宏6)11) & 岡田 & 靖7)11) & 長谷川泰弘 ${ }^{8)} 1$ \\
\hline 七臣9)1 & 奥田 & 聡10)11) & 峰松 & -夫1111) & 豊田 & -則 ${ }^{1111)}$ & \\
\hline
\end{tabular}

要旨 : rt-PA(アルテプラーゼ) 静注療法前の MRI 拡散強調画像(DWI)での早期虚血変化と 転帰の関連を検討した．対象は連続 420 例 (男性 280 例, $71 \pm 11$ 歳). ASPECTS-DWI で領 域別虚血変化を評価し， 3 力月後の mRS 0-2 を転帚良好とした．単変量解析では若年，心房 細動なし, 治療直前 NIHSS スコア低值, ASPECTS-DWI(11 点法)高值, 内頸動脈閉塞なし が転帰良好と関連した(全て P < 0.001). ROC 曲線で求めた転帰良好を予測する ASPECTSDWI の閾值は 7 点(感度 $92 \%$, 特異度 $31 \%$, AUC 0.622)であり, ASPECTS-DWI 7 点以上 は年齢, 性, 治療直前 NIHSS, 高血圧, 心房細動, 内頸動脈閉塞で補正後も有意に転帰良好 に関連した(オッズ比 2.78，95\%信頼区間 1.45-5.49). DWIによる早期虚血変化は rt-PA 静注 療法患者の転帰を検討するうえで有用であった.

Key words : rt-PA, early ischemic change (EIC), ASPECTS, ASPECTS-DWI

(脳卒中 $31: 366-373,2009$ )

\section{はじめに}

National Institute of Neurological Disorders and Stroke(NINDS) 試験1)により虚血性脳血管障害に対す る遺伝子組み換え組織プラスミノゲン・アクティベー ター $(\mathrm{rt}-\mathrm{PA})$ アルテプラーゼ $0.9 \mathrm{mg} / \mathrm{kg}$ 静注による血 栓溶解療法の有用性が示され, 1996 年に米国食品医

\footnotetext{
${ }^{1)}$ 国立循環器病センター内科脳血管部門

2) 川崎医科大学脳卒中医学

3) 杏林大学脳神経外科

4) 中村記念病院脳神経外科

${ }^{5)}$ 広南病院脳血管内科

6) 神戸市立医療センター中央市民病院脳卒中センター

${ }^{7)}$ 国立病院機構九州医療センター脳血管内科

8) 聖マリアンナ医科大学神経内科

${ }^{9)}$ 自治医科大学循環器内科

10) 国立病院機構名古屋医療センター神経内科

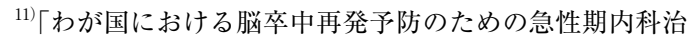
療戦略の確立に関する研究」班

(2009 年 7 月 15 日受付, 2009 年 7 月 16 日受理)
}

薬品局は発症 3 時間以内の虚血性脳血管障害に対する rt-PA 静注療法を認可した。約 10 年後の 2005 年 10 月に, 我が国でも発症 3 時間以内の虚血性脳血管障害 に対する rt-PA 静注療法が承認され，3 年以上が経過 した現在では推定 15,000 例以上に使用されている.

本療法承認の根拠となった Japan Alteplase Clinical Trial $(\mathrm{J}-\mathrm{ACT})^{2)}$ は, 投与量が欧米の $0.9 \mathrm{mg} / \mathrm{kg} に$ に比べ て $0.6 \mathrm{mg} / \mathrm{kg}$ と低用量に設定されたが, 適応基準は NINDS 試験に準拠し, 発症 3 時間以内に治療開始可 能で, CT で早期虚血変化が中大脳動脈領域の $1 / 3$ 未 満の虚血性脳血管障害が対象とされた. rt-PA療法で は, CT による広範な早期虚血変化は出血性合併症の 増加の可能性が危惧されるため, rt-PA 投与禁忌とさ れている.しかし， CT の早期虚血変化の判断には臨 床経験を要すること, 読影者間および読影者内一致度, 再現性などの問題がある゙）．最近は，定量的スコアである Alberta Stroke Programme Early CT Score(ASPECTS) が一般的に使用されるようになってきた ${ }^{4)}$. 脳梗塞急 性期の診断における MRI の拡散強調画像(DWI) は 

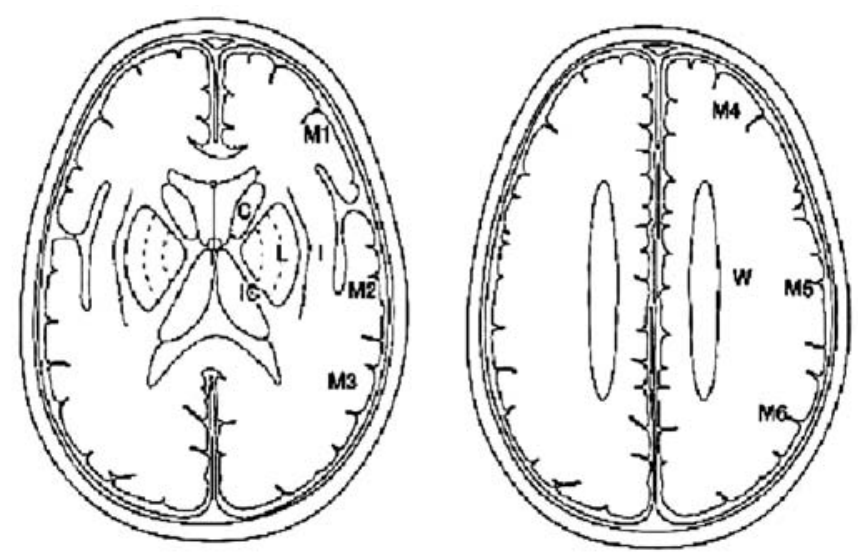

図 1 ASPECTS-DWI

ASPECTS(Alberta stroke Programme Early CT Score)の 10 部位に, 白質(W)を加えた 11 領域で評価する.

$\mathrm{C}:$ caudate(尾状核), L : lentiform(レンズ核), IC $:$ internal capsule(内包後脚), I : insular ribbon(島皮質), MCA : middle cerebral artery, M1 : anterior MCA cortex, M2 : MCA cortex lateral to insular ribbon, M3 : posterior MCA cortex, M4, M5, and M6 are anterior, lateral, and posterior MCA territories immediately superior to M1, M2 and M3, rostral to basal ganglia, W : white matter (白質)

CT と異なり早期虚血変化を明暸に描出することがで きる ${ }^{5) 6}$ が, rt-PA 静注療法時の DWI の有用性に関す る検討は少ない王. 今回, rt-PA 治療脳梗塞患者で DWI の早期虚血変化を ASPECTS で評価し, 頭蓋内出 血および転帚との関連について検討した。

\section{対象と方法}

我々は, 厚生労働科学研究費補助金による循環器疾 患等生活習慣病対策総合研究事業「わが国における脳 卒中再発予防のための急性期内科治療戦略の確立に関 する研究」を実施し, その一環として本研究を行っ た. 研究班に属する 10 施設で 2005 年 10 月から 2008 年 8 月までに rt-PA 静注療法を施行した 600 例 (男性 377 例, 年齢 $72 \pm 12$ 歳)を登録した。 そのうち発症 前 modified Rankin Scale(mRS) 3 以上の 41 例, ペー スペーカー植え込み術後などで rt-PA 投与前に MRI で評価できなかった 77 例(MRI は撮影したが ASPECTS 評価を行えなかった 12 例を含む), 3 力月後の転帰を 追跡することができなかった 62 例を除外し, 残りの 420 例(男性 280 例, $71 \pm 11$ 歳)を対象とした. 脳血 管障害の危険因子, 治療直前 National Institutes of Health Stroke Scale(NIHSS) スコア, DWI の早期虚 血変化, 脳梗塞病型分類, 閉塞血管, 治療開始後 36 時間以内に頭部 CT で認めた頭蓋内出血とそのうち NIHSS スコアが 1 以上増悪した症候性頭蓋内出血,
発症 3 カ月後の $m R S$ を調べた.

DWIに抢ける早期虚血変化は, ASIST-JAPANが 提唱する尾状核 $(\mathrm{C})$, レンズ核 $(\mathrm{L})$, 内包後脚 (IC), 島皮質 (I), M1，M2，M3，M4，M5，M6，白質 (W) からなる ASPECTS-DWI 11 領域(図 1 ；スコア 11 点 は早期虚血変化なし，スコア 0 点は全領域に早期虚血 変化あり；ホームページ, http://asist.umin.jp/)で評価 した. 病型は TOAST 分類 ${ }^{8)}$ に従い, 心原性脳塞栓 症, アテローム血栓性脳梗塞, ラクナ梗塞, 分類不能 の脳梗塞, その他の脳梗塞に分け, 閉塞血管を内頸動 脈, 前大脳動脈, 中大脳動脈 (M1 もしくは M2), 後 大脳動脈, 椎骨動脈, 脳底動脈, 閉塞なし, 評価不能 に分類した. 発症 36 時間以内に頭部 CT で確認され た頭蓋内出血の中で NIHSS 1 以上増悪を症候性頭蓋 内出血と定義し, 頭蓋内出血に関連する因子および 3 カ月後の転帰良好 (mRS 0-2) に関連する因子を検討し た。

統計学的解析にはJMP 7.0 ソフトゥェアを使用し た. 2 群の比較では, 正規分布する連続変数を $\mathrm{t}$ 検 定, カテゴリー変数を $\chi^{2}$ 検定, 非連続変数を MannWhitney の $\mathrm{U}$ 検定で比較し, $\mathrm{P}<0.05$ を有意差あり とした。転帰良好を予測する ASPECTS-DWI の閾値を 受信者動作特性 (ROC) 曲線で求めた．独立した転帰の規 定因子を調べるために，性，年齢と単変量解析で有意で あった因子を用いてロジスティック回帰分析を行った。 
表 1 患者背景

\begin{tabular}{|c|c|}
\hline & $\mathrm{n}=420$ \\
\hline 年齢* & $71 \pm 11$ \\
\hline 男性, n（\%) & $287(66.7)$ \\
\hline 高血圧, n(\%) & $267(63.6)$ \\
\hline 糖尿病, n(\%) & $76(18.1)$ \\
\hline 脂質代謝異常, n（\%） & $89(21.5)$ \\
\hline 心房細動, n（\%) & $173(41.4)$ \\
\hline \multicolumn{2}{|l|}{ 病型分類, n(\%) } \\
\hline 心原性脳塞栓症 & $257(61.1)$ \\
\hline アテローム血检性脳梗塞 & $64(15.2)$ \\
\hline ラクナ梗塞 & $19(4.5)$ \\
\hline 分類不能の脳梗塞 & $39(9.0)$ \\
\hline その他の脳梗塞 & $41(9.5)$ \\
\hline \multicolumn{2}{|l|}{ 閉塞血管 $(\mathrm{n}=391), \mathrm{n}(\%)$} \\
\hline 内頸動脈 & $66(16.9)$ \\
\hline 中大脳動脈 M1 & $121(30.9)$ \\
\hline 中大脳動脈 M2 & $82(21.0)$ \\
\hline 前大脳動脈 & $5(1.3)$ \\
\hline 後大脳動脈 & $13(3.3)$ \\
\hline 椎骨動脈 & $3(0.8)$ \\
\hline 脳底動脈 & $15(3.8)$ \\
\hline 閉塞なし & $86(22.0)$ \\
\hline 発症から治療までの時間 (分) ${ }^{*}$ & $140 \pm 28$ \\
\hline 収縮期血圧 $(\mathrm{mmHg}) *$ & $151 \pm 20$ \\
\hline 拡張期血圧 $(\mathrm{mmHg})^{*}$ & $82 \pm 15$ \\
\hline rt-PA 静注療法直前 NIHSS スコア\# & $12(7-19)$ \\
\hline ASPECTS-DWI スコア\# & $9(7-10)$ \\
\hline
\end{tabular}

rt-PA : recombinant tissue-type plasminogen activator, NIHSS : National Institutes of Health Stroke Scale score *平均 (標準偏差), \#中央值 (4 分位值)

\section{結 果}

対象 420 例中, 高血圧を 267 例 (63.6\%), 糖尿病を 76 例 (18.1\%)，脂質代謝異常を 89 例 (21.5\%)，心房 細動を 173 例 $(41.4 \%)$ に認めた。治療直前 NIHSS 又 コアの中央值は 12 [4 分位值(IQR)7-19], ASPECTSDWI スコアの中央值は 9 点 (IQR 7-10)であった(表 1)。心原性脳塞栓症が 257 例 (61\%) と最も多く, 続い てアテローム血栓性が 64 例(15\%)であった. 閉塞血 管では M1 が 121 例 $(31 \%)$ と最も多く, 続いて M2 閉 塞が 82 例 (21\%), 内頸動脈閉塞が 66 例 (17\%)であっ た. 頭蓋内出血は 87 例 $(21 \%)$ で, 症候性頭蓋内出血
は 17 例 (4\%)であった.

転帰良好(mRS 0-2) は 221 例 (52.6\%)であり，要介 護や死亡を示す mRS 3-6 と比較し, 年齢が若く, 男 性が多く, 高血圧や心房細動の合併が少なく, 治療直 前 NIHSS スコアが低值で，ASPECTS-DWI が高值 で, 内頸動脈閉塞症例が少なかった(単変量解析, 各々 $\mathrm{P}<0.05)$. 単変量解析で有意差が出た因子を用 いて多変量解析を行った結果, 年齢, 性, 治療直前 NIHSS, ASPECTS-DWI, 内頸動脈閉塞症例で有意 差が出た(表 2)。頭蓋内出血に関連する因子は心房細 動の存在, 心原性脳塞栓症, アテローム血栓性以外の 脳梗塞, ASPECTS-DWI の低值であった(単変量解 析, 各々 $\mathrm{P}<0.05)$. 単変量解析で高血圧 $(\mathrm{P}=0.038)$ のみが症候性頭蓋内出血に関連したが, 多変量解析で 関連する因子は検出できなかった。

ASPECTS-DWI が各々 7 点から 11 点までは転帰良 好(mRS 0-2) の割合が $50 \%$ 以上であったが， 6 点以 下になると転帰良好は $25 \%$ 以下， 2 点以下では $0 \%$ と著しく減少した(図 2)。ROC 曲線で求めた転帰良 好を予測する ASPECTS-DWI の闇值は 7 点以上(感 度 $92 \%$, 特異度 $31 \%$, AUC 0.622)であり，転帰良好 は ASPECTS-DWI 7 点以上では $60 \%$ であったのに対 し， 6 点以下では $23 \%$ であった．多変量解析でも ASPECTS-DWI 7 点以上は転帰良好と関連し [年齢, 性補正後オッズ比(OR) 5.37，95\%信頼区間 (CI) 3.03-9.99], 治療直前 NIHSS スコア, 高血圧，心房細 動, 内頸動脈閉塞で補正後にも有意に転帰良好に関連し た(OR 2.78，95\%CI 1.45-5.49). ASPECTS-DWI領 域 別の検討では, 白質 (W) 陽性患者が 191 例 (44\%) と最 も多かったが, 単変量解析では転帰良好と転帰不良で 有意差はなかった。レンズ核 (L)，内包後脚 (IC)，島 皮質(I)，M1，M2，M3，M4，M5 の8部位は転帰良 好例で陽性が少なかった(表 3，モデル 1)，年齢，性 による補正では，M6 以外の 10 力所は転帰良好例で有 意に少なかった(表 3，モデル 2)が，年齢，性，治療直 前 NIHSS スコア，ASPECTS-DWI(総点数)で補正する と全ての領域で有意差が消失した(表 3, モデル 3).

\section{考察}

本研究は, 多施設における多数例で rt-PA 投与前に 撮影した MRIでASPECTS-DWIを評価し，36 時間 以内の頭蓋内出血と 3 力月後の転帰の関連を調べ た. ASPECTS-DWI スコア低值は，転帰良好と負の 関係が，頭蓋内出血と正の関係があったが，症候性頭 
表 2A＼cjkstart転帰良好に寄与する因子

\begin{tabular}{|c|c|c|c|c|c|}
\hline & $\mathrm{mRS} \leq 2(\mathrm{n}=221)$ & $\mathrm{mRS} \geq 3(\mathrm{n}=199)$ & $\mathrm{P}^{\ddagger}$ & オッズ比 (95\%信頼区間) & $\mathrm{P}^{\S}$ \\
\hline 年齢* & $69.2 \pm 11.1$ & $73.8 \pm 9.8$ & $<0.001$ & $0.96(0.94-0.99)$ & 0.009 \\
\hline 男性, n(\%) & $161(72.9)$ & $119(59.8)$ & 0.005 & $1.70(1.02-2.83)$ & 0.040 \\
\hline 高血圧, n(\%) & $129(58.4)$ & $139(70.1)$ & 0.015 & $0.61(0.37-1.00)$ & 0.051 \\
\hline 糖尿病, $\mathrm{n}(\%)$ & $41(18.6)$ & $35(17.6)$ & 0.899 & - & - \\
\hline 脂質代謝異常，n（\%) & $51(23.1)$ & $39(19.7)$ & 0.408 & - & - \\
\hline 心房細動，n(\%) & $75(33.8)$ & $100(50.3)$ & $<0.001$ & $0.76(0.47-1.24)$ & 0.272 \\
\hline 心原性脳塞栓症, $\mathrm{n}(\%)$ & $130(58.9)$ & $128(64.3)$ & 0.270 & - & - \\
\hline 発症から治療までの時間(分)* & $139.1 \pm 27.0$ & $140.8 \pm 28.3$ & 0.529 & - & - \\
\hline 収縮期血圧 $(\mathrm{mmHg})^{*}$ & $151.6 \pm 20.0$ & $151.5 \pm 19.8$ & 0.972 & - & - \\
\hline 拡張期血圧 $(\mathrm{mmHg})^{*}$ & $82.9 \pm 15.1$ & $81.8 \pm 14.5$ & 0.481 & - & - \\
\hline rt-PA 静注療法直前 NIHSS スコア\# & \# $9(6-14)$ & $17(11-21)$ & $<0.001$ & $0.93(0.90-0.97)^{\natural}$ & $<0.001$ \\
\hline ASPECTS-DWI スコア\# & $9(8-10)$ & $8(6-10)$ & $<0.001$ & $1.16(1.03-1.31)^{\natural}$ & 0.014 \\
\hline 内頸動脈閉塞 (\%), n(\%) & $9(3.9)$ & $60(30.4)$ & $<0.001$ & $0.14(0.06-0.29)$ & $<0.001$ \\
\hline 中大脳動脈 $\mathrm{M} 1$ 閉塞 (\%), $\mathrm{n}(\%)$ & $66(30.2)$ & $63(31.9)$ & 0.744 & - & - \\
\hline 中大脳動脈 $\mathrm{M} 2$ 閉塞 (\%), $\mathrm{n}(\%)$ & $56(25.3)$ & $33(16.8)$ & 0.048 & - & - \\
\hline
\end{tabular}

*平均 (標準偏差), ${ }^{*}$ 中央值 $(4$ 分位值)

${ }^{*} \mathrm{t}$ 検定， $\chi^{2}$ 検定もしくは Mann-Whitney $U$ 検定の有意確率

$\S$ 年齢, 性別, 高血圧, 心房細動, rt-PA 静注療法直前 NIHSS スコア, ASPECTS-DWI スコア, 内頸動脈閉塞で多变量 ロジスティック回帰分析を施行

${ }^{n} 1$ ポイント増加あたりのオッズ比

表 2B 頭蓋内出血に寄与する因子(単変量解析)

\begin{tabular}{|c|c|c|c|c|c|c|}
\hline & $\begin{array}{c}\text { ICH } \\
(n=87)\end{array}$ & $\begin{array}{l}\text { No ICH } \\
(\mathrm{n}=333)\end{array}$ & $\mathrm{P}^{\ddagger}$ & $\begin{array}{c}\text { sICH } \\
(\mathrm{n}=17)\end{array}$ & $\begin{array}{l}\text { No sICH } \\
(\mathrm{n}=393)\end{array}$ & $\mathrm{P}^{\ddagger}$ \\
\hline 年齢* & $72.5 \pm 9.2$ & $71.1 \pm 11.1$ & 0.265 & $72.5 \pm 7.7$ & $71.31 \pm 0.8$ & 0.655 \\
\hline 男性，n（\%) & $59(67.8)$ & $222(66.8)$ & 0.899 & $13(76.5)$ & $262(66.6)$ & 0.599 \\
\hline 高血圧, n(\%) & $61(70.6)$ & $207(62.2)$ & 0.165 & $15(88.2)$ & $247(62.9)$ & 0.038 \\
\hline 糖尿病， n（\%） & $13(14.9)$ & $63(19.0)$ & 0.437 & $4(23.5)$ & $71(18.0)$ & 0.526 \\
\hline 脂質代謝異常, n（\%) & $17(19.5)$ & $73(21.8)$ & 0.769 & $6(35.3)$ & $82(20.9)$ & 0.221 \\
\hline 心房細動，n（\%) & $52(59.3)$ & $123(37.0)$ & 0.001 & $9(52.9)$ & $162(41.1)$ & 0.452 \\
\hline 心原性脳塞栓症, n（\%） & $65(74.7)$ & $193(58.0)$ & 0.004 & $13(76.5)$ & $239(60.9)$ & 0.308 \\
\hline 発症から治療までの時間(分) * & $140.4 \pm 25.1$ & $139.8 \pm 28.3$ & 0.855 & $138.8 \pm 27.1$ & $140.0 \pm 27.7$ & 0.869 \\
\hline 収縮期血圧 $(\mathrm{mmHg})^{*}$ & $151.1 \pm 20.3$ & $151.0 \pm 18.5$ & 0.959 & $157.1 \pm 18.2$ & $150.8 \pm 20.0$ & 0.203 \\
\hline 拡張期血圧 $(\mathrm{mmHg})^{*}$ & $81.5 \pm 15.4$ & $82.4 \pm 14.5$ & 0.610 & $83.8 \pm 10.0$ & $82.2 \pm 14.8$ & 0.648 \\
\hline rt-PA 静注療法直前 NIHSS スコア\# & $15(8-19)$ & $12(7-18)$ & 0.080 & $13(7-19)$ & $12(7-19)$ & 0.995 \\
\hline ASPECTS-DWI スコア\# & $8(6-10)$ & $9(7-10)$ & 0.009 & $8(6-10)$ & $9(7-10)$ & 0.456 \\
\hline 内頸動脈閉塞 (\%), n(\%) & $19(22.1)$ & $51(15.3)$ & 0.144 & $3(18.8)$ & $66(16.7)$ & 0.739 \\
\hline 中大脳動脈 M1 閉塞 (\%), n(\%) & $32(37.2)$ & $98(29.3)$ & 0.187 & $6(37.5)$ & $121(30.8)$ & 0.587 \\
\hline 中大脳動脈 M2 閉塞 (\%), n(\%) & $16(18.6)$ & $73(21.8)$ & 0.554 & $3(18.8)$ & $83(21.2)$ & 1.000 \\
\hline
\end{tabular}

ICH : 治療開始後 36 時間以内に頭蓋内出血を認めた症例, No ICH : 治療開始後 36 時間以内に頭蓋内出血を認めな かった症例, sICH : 治療開始後 36 時間以内に症候性頭蓋内出血を認めた症例, No sICH : 治療開始後 36 時間以内に 症候性頭蓋内出血を認めなかった症例

*平均(標準偏差), ${ }^{*}$ 中央值 (4 分位值), ${ }^{\ddagger} \mathrm{t}$ 検定, $\chi^{2}$ 検定もしくは Mann-Whitney U 検定の有意確率 


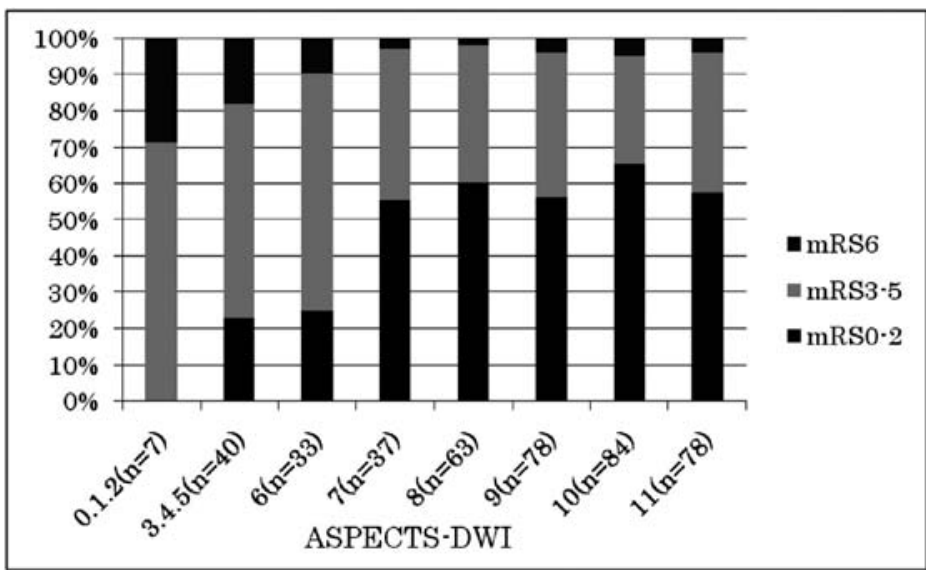

図 2 ASPECTS-DWI スコア毎の 3 カ月後 mRS

表 3 ASPECTS-DWI 領域別の早期虚血変化陽性患者の割合

\begin{tabular}{|c|c|c|c|c|c|}
\hline & $\mathrm{mRS} \leq 2(\mathrm{n}=221)(\%)$ & $\mathrm{mRS} \geq 3(\mathrm{n}=199)(\%)$ & モデル $1 \quad \mathrm{P}$ & モデル $2 \mathrm{P}$ & モデル 3 \\
\hline $\mathrm{C}(\mathrm{n}=48)$ & 9 & 15 & 0.065 & 0.021 & 0.882 \\
\hline $\mathrm{L}(\mathrm{n}=97)$ & 19 & 28 & 0.038 & 0.015 & 0.868 \\
\hline $\mathrm{IC}(\mathrm{n}=60)$ & 11 & 18 & 0.037 & 0.031 & 0.124 \\
\hline $\mathrm{I}(\mathrm{n}=181)$ & 35 & 52 & $<0.001$ & 0.002 & 0.170 \\
\hline $\mathrm{M} 1(\mathrm{n}=85)$ & 13 & 29 & $<0.001$ & $<0.001$ & 0.997 \\
\hline $\mathrm{M} 2(\mathrm{n}=90)$ & 16 & 31 & $<0.001$ & $<0.001$ & 0.742 \\
\hline $\mathrm{M} 3(\mathrm{n}=51)$ & 9 & 18 & 0.006 & 0.002 & 0.386 \\
\hline $\mathrm{M} 4(\mathrm{n}=56)$ & 9 & 20 & 0.002 & 0.011 & 0.602 \\
\hline $\mathrm{M} 5(\mathrm{n}=118)$ & 23 & 35 & 0.007 & 0.025 & 0.920 \\
\hline $\mathrm{M} 6(\mathrm{n}=68)$ & 14 & 20 & 0.154 & 0.138 & 0.530 \\
\hline $\mathrm{W}(\mathrm{n}=191)$ & 44 & 52 & 0.118 & 0.043 & 0.513 \\
\hline
\end{tabular}

モデル 1：単変量解析(Fisher 直接法)

モデル 2: 多変量解析 (年齢, 性により補正)

モデル 3: 多変量解析(年齢, 性, 治療前 NIHSS, ASPECTS-DWI スコアにより補正)

C : caudate(尾状核), L : lentiform(レンズ核), IC : internal capsule(内包後脚), I : insular ribbon(島皮質), MCA : middle cerebral artery, M1 : anterior MCA cortex, M2 : MCA cortex lateral to insular ribbon, M3 : posterior MCA cortex, M4, M5, and M6 are anterior, lateral, and posterior MCA territories immediately superior to M1, M2 and M3, rostral to basal ganglia, W : white matter(白質)

蓋内出血には関係なかった，ROC 曲線を用いた解析 では, ASPECTS-DWI 7 点以上が転帰良好を予測す る閾值であり，ASPECTS-DWI 7 点以上は独立して転 帰良好に関連した，我々が調べた限りでは，これまで にrt-PA 静注療法前の DWIに扔ける早期虚血変化と 3 カ月後の転帰の関連を多施設で検討した報告はない.

一般的に虚血性脳血管障害患者に対する rt-PA 静注
療法時には CT で早期虚血変化を評価し, 我々が遵守 している rt-PA 静注療法適正使用指針によれば CT 上 で広範な早期虚血変化を認める場合は rt-PA 療法の禁 忌とされる ${ }^{9)}$. しかし， CT の早期虚血変化が rt-PA 静

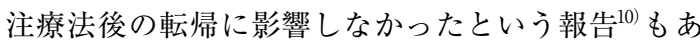
り, 読影者の問題, 再現性の問題などが指摘され, CT における早期虚血変化の定量化や, 新たな早期虚 
血変化の評価方法が求められてきだ3). Barber らが提 唱した ASPECTSはMCA 領域の早期虚血変化を 10 点満点で定量化する方法であり, 彼らは rt-PA 静注療 法患者でASPECTS 8 点以上が転帰良好 (3力月後 mRS 0-2) と関連することを報告している ${ }^{4)}$. CT に比 べDWIを用いると急性期脳梗塞における早期虚血変 化を感度よく検出でき, 画像の分解能も高く, 診断が 比較的容易にできる ${ }^{4) 5)}$. しかし rt-PA 静注療法前に 評価した DWI の有効性の検討は少なく, 超急性期の DWI の早期虚血所見が患者の転帰にどのように影響 するかに関しては不明な点が多い. CTと DWIの ASPECTSを比較検討し, DWI CTよりも早期虚 血変化の検出感度が高いが, ASPECTS を使用すると その差はわずかであると報告されている ${ }^{11)}$. 一方で, rt-PA 静注療法を施行した急性期脳梗塞患者 49 例を 対象に, DWI-ASPECTS (10 点法) で 5 点以下が多変 量解析後も治療 1 週間後の転帰不良 (NIHSS 20 以上) と独立して関連することが示されている ${ }^{6)}$. また, rt-PA 静注療法を施行した急性期脳梗塞患者 78 例を 対象とした検討ではDWI-ASPECTS(10 点法)で 7 点 以上が 3 力月後の転帰良好 (mRS 0-1) と関連すること を示している ${ }^{12)}$.

MRI は急性期脳梗塞診療で CTよりも診断感度な ど様々な点で優れている，まず, DWI と perfusion weighted imaging $(\mathrm{PWI})$ を組み合わせることでペナン ブラ領域を反映するとされる DWI-PWI ミスマッチを 評価でき, 症例によって time window を延長できる ことも示唆されている ${ }^{13)}$ 16). 次に, MR angiography (MRA)の併用により主幹動脈閉塞を評価できる. 主 幹動脈の閉塞部位と DWI 領域の体積から評価する MRA-DWI ミスマッチ ${ }^{17)}$ は血栓溶解療法の効果予測に 有用とされる. また, 今回の結果からも明らかになっ た治療効果のそしい近位主幹動脈閉塞例を検出し ${ }^{18)}$,

効果が期待される Merci Retriever ${ }^{19)} や$ Penumbra ${ }^{20)}$ などの新規デバイスの使用や, 局所血栓溶解療法の併 用を検討することが可能となる. MRIの撮像時間の 長さや急性期脳出血の除外の問題点が指摘されてきた が, 発症 3 時間以内の rt-PA 療法症例に MRI を用い ても転帰に影響するような時間的制約によるデメ リットは認められていない21222). 脳出血は $\mathrm{T} 2$ *強調画 像の併用で除外可能であり ${ }^{2324)}$, ペースメーカー植え 込みなどの特殊事情がない限り MRIにおけるデメ リットはほとんどないと考えられる。

本検討では, いくつかの未解決の問題点がある.
ASPECTS では DWI 上の信号変化の程度を評価でき ない. DWI で淡い高信号の部位は可逆的変化である 可能性があり, その評価に拡散係数 (apparent diffusion coefficient: ADC) 用いる研究が成されている.

しかし脳梗塞になる領域と可逆領域を判別する ADC の閾值は明らかではなく25) 27), 今後の更なる検討が 必要であろう。また, ASPECTSは各領域内の病変の 拡がりを反映して扔らず，各領域内の微小な変化をス コアに入れるべきかなどの検討も必要であろう．最後 に, 本研究は rt-PA 静注療法例のみを対象とした観察 研究であり, 本研究の結果のみから ASPECTS-DWI 低值の症例を rt-PA 療法の適応外と判断してはいけな い. なぜならば ASPECTS-DWI の低值は広範囲の脳梗 塞を示しており,このような症例はrt-PA 静注療法の 有無に関わらず転帰が不良と予測されるからである.

本研究では発症 3 時間以内の rt-PA 療法症例の DWIによる早期虚血変化を ASPECTS で評価し, ASPECTS-DWI 7 点以上が転州良好に独立して関連 することを示した. DWI を含めた頭部 MRI 検査は, 急性期脳卒中診療の現場において血栓溶解療法の適応 の選択やその転帰予測, therapeutic time windowの 延長などに関する非常に重要な情報を与え, その有用 性は増していくものと期待される.

\section{謝辞}

本研究は厚生労働科学研究費補助金に上る循環器疾患等生 活習慣病対策総合研究事業「わが国における脳卒中再発予防 のための急性期内科治療戦略の確立に関する研究」(主任研究 者：豊田一則)の助成によってなされた。

*本論文の要旨は, 「脳梗塞 t-PA 研究会」第 3 回研究集会で 発表した。

\section{文献}

1) Tissue plasminogen activator for acute ischemic stroke. The National Institute of Neurological Disorders and Stroke rt-PA Stroke Study Group. N Engl J Med 333: 1581-1587, 1995

2) Yamaguchi T, Mori E, Minematsu K, et al: Alteplase at $0.6 \mathrm{mg} / \mathrm{kg}$ for acute ischemic stroke within 3 hours of onset: Japan Alteplase Clinical Trial (J-ACT). Stroke 37: 1810-1815, 2006

3) Wardlaw JM, Mielke O: Early signs of brain infarction at CT: observer reliability and outcome after thrombolytic treatment-systematic review. Radiology 235: 444-453, 2005

4) Barber PA, Demchuk AM, Zhang J, et al: Validity 
and reliability of a quantitative computed tomography score in predicting outcome of hyperacute stroke before thrombolytic therapy. ASPECTS Study Group. Alberta Stroke Programme Early CT Score. Lancet 355: 1670-1674, 2000

5) Lansberg MG, Albers GW, Beaulieu C, et al: Comparison of diffusion-weighted MRI and CT in acute stroke. Neurology 54: 1557-1561, 2000

6) Barber PA, Darby DG, Desmond PM, et al: Identification of major ischemic change. Diffusionweighted imaging versus computed tomography. Stroke 30: 2059-2065, 1999

7) Kimura K, Iguchi $Y$, Shibazaki K, et al: Large ischemic lesions on diffusion-weighted imaging done before intravenous tissue plasminogen activator thrombolysis predicts a poor outcome in patients with acute stroke. Stroke 39: 2388-2391, 2008

8) Adams HP Jr, Bendixen BH, Kappelle LJ, et al: Classification of subtype of acute ischemic stroke. Definitions for use in a multicenter clinical trial. TOAST. Trial of Org 10172 in Acute Stroke Treatment. Stroke 24: 35-41, 1993

9) Hacke W, Kaste M, Fieschi C, et al: Randomised double-blind placebo-controlled trial of thrombolytic therapy with intravenous alteplase in acute ischaemic stroke (ECASS II). Second EuropeanAustralasian Acute Stroke Study Investigators. Lancet 352: 1245-1251, 1998

10) Patel SC, Levine SR, Tilley BC, et al: Lack of clinical significance of early ischemic changes on computed tomography in acute stroke. JAMA 286: 2830-2838, 2001

11) Barber PA, Hill MD, Eliasziw M, et al: Imaging of the brain in acute ischaemic stroke: comparison of computed tomography and magnetic resonance diffusion-weighted imaging. J Neurol Neurosurg Psychiatry 76: 1528-1533, 2005

12) Nakashima T, Toyoda K, Koga M, et al: Arterial occlusion sites on MRA influence the efficacy of intravenous low-dose $(0.6 \mathrm{mg} / \mathrm{kg})$ alteplase therapy for ischemic stroke. Int J Stroke 2009 (in press)

13) Hacke W, Albers G, Al-Rawi Y, et al: The Desmoteplase in Acute Ischemic Stroke Trial (DIAS): a phase II MRI-based 9-hour window acute stroke thrombolysis trial with intravenous desmoteplase. Stroke 36: 66-73, 2005

14) Furlan AJ, Eyding D, Albers GW, et al: Dose Escalation of Desmoteplase for Acute Ischemic Stroke (DEDAS): evidence of safety and efficacy 3 to 9 hours after stroke onset. Stroke 37: 12271231, 2006

15) Albers GW, Thijs VN, Wechsler L, et al: Magnetic resonance imaging profiles predict clinical response to early reperfusion: the diffusion and perfusion imaging evaluation for understanding stroke evolution (DEFUSE) study. Ann Neurol 60: 508-517, 2006

16) Davis SM, Donnan GA, Parsons MW, et al: Effects of alteplase beyond $3 \mathrm{~h}$ after stroke in the Echoplanar Imaging Thrombolytic Evaluation Trial (EPITHET): a placebo-controlled randomised trial. Lancet Neurol 7: 299-309, 2008

17) Lansberg MG, Thijs VN, Bammer R, et al: The MRA-DWI mismatch identifies patients with stroke who are likely to benefit from reperfusion. Stroke 39: 2491-2496, 2008

18) Derex L, Hermier M, Adeleine P, et al: Influence of the site of arterial occlusion on multiple baseline hemodynamic MRI parameters and post-thrombolytic recanalization in acute stroke. Neuroradiology 46 : 883-887, 2004

19) Flint AC, Duckwiler GR, Budzik RF, et al: Mechanical thrombectomy of intracranial internal carotid occlusion: pooled results of the MERCI and Multi MERCI Part I trials. Stroke 38: 1274-1280, 2007

20) Bose A, Henkes H, Alfke K, et al: The Penumbra System: a mechanical device for the treatment of acute stroke due to thromboembolism. AJNR Am J Neuroradiol 29: 1409-1413, 2008

21) Kang DW, Chalela JA, Dunn W, et al: MRI screening before standard tissue plasminogen activator therapy is feasible and safe. Stroke 36: 1939-1943, 2005

22) Schellinger PD, Thomalla G, Fiehler J, et al: MRIbased and CT-based thrombolytic therapy in acute stroke within and beyond established time windows: an analysis of 1210 patients. Stroke 38: 2640-2645, 2007

23) Linfante I, Llinas RH, Caplan LR, et al: MRI features of intracerebral hemorrhage within 2 hours from symptom onset. Stroke 30: 2263-2267, 1999

24) Kakuda W, Thijs VN, Lansberg MG et al: Clinical importance of microbleeds in patients receiving IV thrombolysis. Neurology 65: 1175-1178, 2005

25) Desmond PM, Lovell AC, Rawlinson AA, et al: The value of apparent diffusion coefficient maps in early cerebral ischemia. AJNR Am J Neuroradiol 22: 1260-1267, 2001

26) Bykowski JL, Latour LL, Warach S: More accurate identification of reversible ischemic injury in human stroke by cerebrospinal fluid suppressed diffusion-weighted imaging. Stroke 35: 1100-1106, 2004

27) Loh PS, Butcher KS, Parsons MW, et al: Apparent diffusion coefficient thresholds do not predict the response to acute stroke thrombolysis. Stroke 36: 2626-2631, 2005 


\title{
Abstract \\ Pre-treatment ASPECTS-DWI score has a relation with functional outcome at 3 months following intravenous rt-PA therapy
}

\author{
Tomohisa Nezu, M.D. ${ }^{111)}$, Masatoshi Koga, M.D. ${ }^{111)}$, Masaki Naganuma, M.D. ${ }^{111)}$, \\ Kazumi Kimura, M.D. ${ }^{211)}$, Yoshiaki Shiokawa, M.D. ${ }^{311}{ }^{11}$, Jyoji Nakagawara, M.D. ${ }^{4) 11}$, \\ Eisuke Furui, M.D. ${ }^{511)}$, Hiroshi Yamagami, M.D. ${ }^{6)}{ }^{11}$, Yasushi Okada, M.D. ${ }^{711}$, \\ Yasuhiro Hasegawa, M.D. ${ }^{811)}$, Kazuomi Kario, M.D. ${ }^{911)}$, Satoshi Okuda, M.D. ${ }^{10) 11}$, \\ Kazuo Minematsu, M.D. ${ }^{111)}$ and Kazunori Toyoda, M.D. ${ }^{111)}$ \\ ${ }^{1)}$ Cerebrovascular Division, Department of Medicine, National Cardiovascular Center \\ ${ }^{2}$ Department of Stroke Medicine, Kawasaki Medical School \\ ${ }^{3)}$ Departments of Neurosurgery, and Stroke Center, Kyorin University School of Medicine \\ ${ }^{4)}$ Department of Neurosurgery and Stroke Center, Nakamura Memorial Hospital \\ ${ }^{5)}$ Department of Stroke Neurology, Kohnan Hospital \\ ${ }^{6}$ Department of Neurology, Stroke Center, Kobe City General Hospital \\ ${ }^{7)}$ Department of Cerebrovascular Disease, National Hospital Organization Kyushu Medical Center \\ ${ }^{8)}$ Department of Neurology, St Marianna University School of Medicine \\ ${ }^{9}$ Division of Cardiovascular Medicine, Department of Medicine, Jichi Medical University School of Medicine \\ ${ }^{10)}$ Department of Neurology, National Hospital Organization Nagoya Medical Center \\ ${ }^{11)}$ Stroke Acute Management with Urgent Risk-factor Assessment and \\ Improvement (SAMURAI) Study Investigators
}

Background and Purpose: The clinical importance of early ischemic changes (EIC) on DWI before rt-PA thrombolysis has not been elucidated well. The present study aimed evaluating whether ASPECTS-DWI before rt-PA therapy could predict chronic independent outcome. Methods: Consecutive stroke patients treated with rt-PA from October 2005 through July 2008 were registered from 10 major stroke centers located without regional imbalance in Japan. Before rt-PA IV infusion, we assessed EIC on DWI by using ASPECTS-DWI (11 points). Independent outcome was defined by modified Rankin Scale score (mRS) 0-2 at 3 months after stroke onset. Results: A total of 420 patients (280 men, $71 \pm 11$ years in age) were studied, and 221 (52.6\%) of them were independent (mRS 0-2) at 3 months. The independent patients were younger, had less hypertension and atrial fibrillation, lower baseline NIHSS score, higher ASPECTS-DWI, less internal carotid artery occlusion than dependent patients (mRS 3-6, P $<0.05$ for all). The optimal cutoff score of ASPECTS-DWI to predict independent outcome was $\geq 7$ with a sensitivity of $92 \%$ and specificity of $31 \%$, and the area under the receiver-operating characteristic curve was 0.622 . After multivariate logistic regression analysis, ASPECTS-DWI $\geq 7$ was independently predictive of an independent outcome at 3 months (OR 2.78, 95\% CI 1.45-5.49). Conclusion: ASPECTSDWI before rt-PA therapy is useful to predict patients' chronic functional outcome.

(Jpn J Stroke 31: 366-373, 2009) 